Int. J. Electrochem. Sci., 12 (2017) $1612-1624$

\title{
Carbon Paste Electrode with Au/Pd/MWCNT Nanocomposite for Nanomolar Determination of Timolol
}

\author{
Khadijeh Nekoueian ${ }^{1, *}$, Mandana Amiri ${ }^{2}$, Mika Sillanpää ${ }^{1}$ \\ ${ }^{1}$ Laboratory of Green Chemistry, Faculty of Technology, Lappeenranta University of Technology, \\ Sammonkatu 12, FI-50130 Mikkeli, Finland \\ ${ }^{2}$ Department of Chemistry, University of Mohaghegh Ardabili, Ardabil, Iran \\ *E-mail: kh.nekoueian@gmail.com
}

doi: $10.20064 / 2017.02 .56$

Received: 25 October 2016 / Accepted: 22 December 2016 / Published: 30 December 2016

\begin{abstract}
Fabrication of $\mathrm{Au} / \mathrm{Pd} / \mathrm{MWCNT}$ nanocomposite was performed by using chemical method. The nanocomposite was characterized by scanning electron microscopy (SEM), energy-dispersive X-Ray spectroscopy (EDS) and electrochemical methods. Palladium and gold nanoparticles were dispersed in multi-walled carbon nanotubes (MWCNT). The Au/Pd/MWCNT nanocomposite was applied as a modifier in carbon paste electrode for electro-oxidation of timolol. This modified electrode displayed high efficiency for sub-micromolar determination of timolol maleate. The effect of $\mathrm{pH}$ of the buffered solutions and potential sweep rate on the response of the electrode for the oxidation of timolol were investigated. Differential pulse voltammetry was used for quantitative determination. Dynamic linear ranges were obtained in the two ranges of $1.0 \times 10^{-5}-1.0 \times 10^{-3} \mathrm{M}$ and $5.0 \times 10^{-9}-8.0 \times 10^{-7} \mathrm{M}$ and the detection limit was estimated to be $5.8 \times 10^{-11} \mathrm{M}$. The practical utility of this modified electrode was investigated by detecting timolol maleate in pharmaceutical sample (eye drop) and synthetic serum.
\end{abstract}

Keywords: Timolol maleate, Pd nanoparticles, Au nanoparticles, Multi-walled carbon nanotubes, Voltammetric sensor

\section{FULL TEXT}

(C) 2017 The Authors. Published by ESG (www.electrochemsci.org). This article is an open access article distributed under the terms and conditions of the Creative Commons Attribution license (http://creativecommons.org/licenses/by/4.0/). 